\title{
Endangered by trade: seizure analysis of the critically endangered Philippine Forest Turtle Siebenrockiella leytensis from 2004-2018
}

\author{
Emerson Y. Sy ${ }^{1,6 *}$, Sabine Schoppe ${ }^{2}$, Mae Lowe L. Diesmos ${ }^{3,6}$, Theresa Mundita S. Lim ${ }^{4}$, \\ and Arvin C. Diesmos ${ }^{5,6}$
}

\begin{abstract}
The Philippine or Palawan Forest Turtle Siebenrockiella leytensis is the only endemic turtle known to occur in the Philippines. It was assessed as Critically Endangered in 2000 and has been considered as one of the world's top 25 most endangered turtles since 2003. The species is accorded protection nationally by the Wildlife Protection and Conservation Act of 2001 and its international commercial trade is regulated by the Convention on International Trade in Endangered Species (CITES). However, the publication of its rediscovery in 2004 triggered unrelenting poaching and trafficking for the pet trade nationally and internationally. With the aim of quantifying the extent of poaching and to provide insight on the trade dynamics, we analyzed seizure records from 2004-2018 and conducted physical and online market surveys in 2017-2018. Twenty-three (23) seizure incidents involving 4,723 Philippine Forest Turtles were recorded in the last 15 years. Based on an online survey, we estimated that an additional 1,200 Philippine Forest Turtles were smuggled and illegally sold in China in 2015. The majority of the 74 live individuals exported legally from the Philippines were likely sourced illegally from the wild and declared fraudulently as captive bred by exporters to obtain CITES permits. While habitat loss or degradation is a major threat, the illegal pet trade remains the most important factor threatening the survival of the Philippine Forest Turtles in the wild.
\end{abstract}

Keywords: chelonian, CITES, pet trade, trafficking, wildlife laundering

\footnotetext{
${ }^{1}$ TRAFFIC Southeast Asia Regional Office, Suite 12A-01, Tower 1 Wisma AmFirst, Jalan Stadium SS 7/15, 47301, Kelana Jaya, Petaling Jaya, Selangor, Malaysia

${ }^{2}$ Katala Foundation, Incorporated, Casoy Road, Purok El Rancho, Barangay Santa Monica, Puerto Princesa City 5300, Palawan, Philippines

${ }^{3}$ Department of Biological Sciences, College of Science, University of Santo Tomas, España, 1015 Manila, Philippines

${ }^{4}$ ASEAN Centre for Biodiversity, Domingo M. Lantican Avenue, Los Baños, Laguna 4031, Philippines

${ }^{5}$ Herpetology Section, Zoology Division, Philippine National Museum of Natural History, T.F. Valencia Circle, T.M. Kalaw Avenue, Rizal Park, 1000 Manila, Philippines

${ }^{6}$ HerpWatch Pilipinas, Benavidez Street, Tondo, Manila, Philippines
}

*Corresponding email: emersonsy@gmail.com

Date Submitted: 23 June 2019

Date Accepted: 09 June 2020

\section{Introduction}

The Philippine or Palawan Forest Turtle Siebenrockiella leytensis (Taylor) [syn. Heosemys leytensis] is the largest terrestrial and the only endemic turtle known to occur in the Philippines (Fig. 1). Adult turtles reach a median carapace length of over $300 \mathrm{~mm}$ and can weigh as much as $3.5 \mathrm{~kg}$ (Diesmos et al., 2012). Locally known as "Bakoko" in the Cuyonon language of Palawan Province where it is endemic to, the species was scientifically described by Edward H. Taylor in 1920 based on two specimens apparently collected on Leyte Island. Numerous attempts to locate natural populations of the turtle on Leyte and other islands failed to turn up additional specimens, prompting herpetologists to categorize the species as rare (Alcala, 1986), critically endangered (IUCN/SSC Tortoise and Freshwater Turtle Specialist Group and Asian Turtle Trade Working Group, 2000), and one of the world's top 25 most endangered turtles (Turtle Conservation Fund, 2003). 
In 1987, a live individual purchased from a local resident in Palawan Province provided a new locality record for the species (Timmerman \& Auth, 1988). The discovery of natural populations of Philippine Forest Turtle on the islands of Palawan and Dumaran in 2001 unraveled the true geographic distribution of the species (Diesmos et al., 2004). While the Philippine Forest Turtle is nationally protected under Republic Act No. 9147 (Wildlife Resources Conservation and Protection Act of 2001) and has been listed in Appendix II of the Convention on International Trade in Endangered Species of Wild Fauna and Flora (CITES) since 2003 to regulate international commercial trade, the news about the rediscovery of the apparently endangered species resulted to a significant increase in demand from turtle enthusiasts in both local and international reptile pet black markets. Just a few months after the publication of the report, live individuals of the species were documented to be on sale in the Philippines, Japan, Malaysia, Europe, and the United States (Diesmos et al., 2012; Schoppe et al., 2013; Sy, 2018). The availability of the Philippine Forest Turtle has since then been observed in physical markets in Metro Manila and domestic and international online markets (Sy, 2015, 2018; Jansen and Sy, in press). Under the R.A. No. 9147, illegal collection and possession of critically endangered species, including the Philippine Forest Turtle, may be sentenced with up to four years of imprisonment and PHP300,000 (USD5,660) fine.

In the last 15 years, enforcement efforts by Philippine wildlife authorities resulted to numerous seizures of illegallytraded wildlife including the Philippine Forest Turtle. With the aim of quantifying the extent of poaching and illegal trade of this species, we (1) analyzed seizure and international legal trade records and (2) conducted market surveys to provide insights into the trade dynamics and to highlight challenges in conservation efforts of this critically endangered species.

\section{Methodology}

Unpublished seizure records over a 15 -year period from 2004-2018 were obtained from the Philippines' Biodiversity Management Bureau of the Department of Environment and Natural Resources (DENR-BMB) and Palawan Council for Sustainable Development Staff (PCSDS). The latter is the primary government agency that is mandated to safeguard the biodiversity of Palawan Province in the Philippines. Additional data from newspaper articles, police reports, and nongovernmental organizations (NGOs) were gathered to supplement available data from official records. All information was combined into a single dataset and analyzed to determine seizure location, quantity, and date of seizures. One seizure

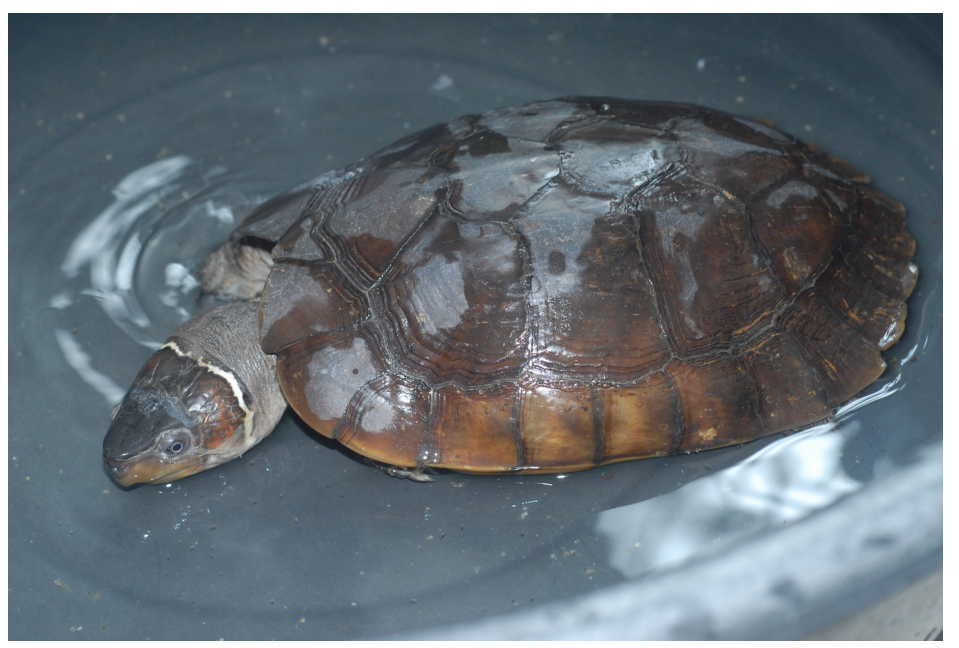

Figure 1. The Philippine Forest Turtle Siebenrockiella leytensis is currently the only known endemic chelonian in the Philippines.

(C) Emerson Y. Sy

incident in Leyte Province in 2017 misidentified 40 Southeast Asian Box Turtle Cuora amboinensis Daudin as Philippine Forest Turtles (Cayubit, 2017; Sy, unpubl. data). This particular seizure was therefore omitted from the dataset.

Online (e.g. Facebook) and physical market surveys were conducted concurrently between January 2017 and December 2018. TRAFFIC researchers conducted an online survey from January 2017 to December 2018 by monitoring the activities of 20 Facebook groups specializing in the trade of live reptiles in the Philippines. Advertisements offering to sell live Philippine Forest Turtles were extracted and information such as URL, quantity, and price of each advertisement were documented. Duplicate advertisements posted by the same trader in several groups were removed from the dataset to avoid inflating the total available individual turtles in the trade. One of us (EYS) conducted quarterly physical market surveys at random time and date in Cartimar Pet Center, National Capital Region (NCR) during the same period.

We presumed that all live Philippine Forest Turtles were sourced in Palawan Province since the species naturally occurs only in the province. There are no known facilities anywhere in the world that are breeding the species for commercial purposes.

\section{Results}

A total of 23 seizure incidents involving 4,723 Philippine Forest Turtles were documented in the last 15 years (Fig. 2). Majority of seizures occurred on Palawan (15 incidents) and Luzon (5 incidents) islands (Fig. 3). Seizure incidents peaked in 2015 with 10 cases involving a total of 4,283 individuals or $91 \%$ of the total quantity seized in the last 15 years. This was largely attributed to a single record seizure of freshwater turtles in the 


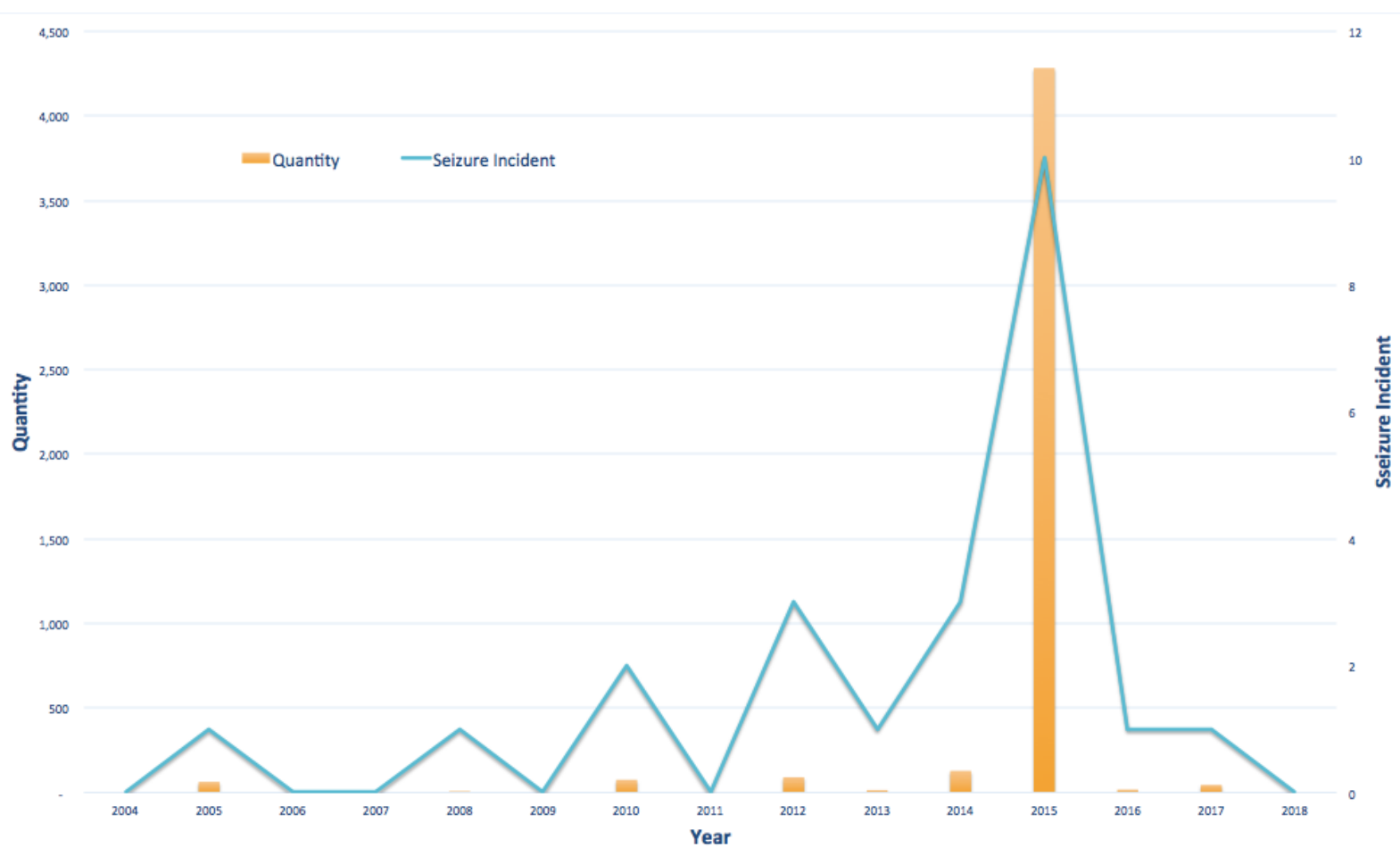

Figure 2. Seizure incidents and seized quantity of Philippine Forest Turtle from 2004-2018.

Philippines that involved 4,402 individuals, of which 3,921 were Philippine Forest Turtles (3,831 live and 90 dead). This seizure, which represents $83 \%$ of Philippine Forest Turtle seized over the 15-year period occurred in Barangay Rio Tuba, Municipality of Bataraza, Palawan Province on 17 June 2015 (Devanadera et al., 2015; Fig. 4).

\section{Arrests and outcomes}

At least 12 out of 23 incidents resulted to the arrest of 21 suspected traffickers. However, only two suspects were convicted, fined, and served jail sentences: one trafficker was convicted twice in Hong Kong after he was caught in February 2012 with 36 Philippine turtles including 20 Philippine Forest Turtles and again in June 2012 with 137 Philippine reptiles including 43 Philippine Forest Turtles. Another suspect who was arrested in Quezon City with 27 Philippine Forest Turtles in 2014 was later convicted in 2018. The court case of another suspect arrested in Pasay City in 2014 may have been dropped. It is uncertain if Philippine wildlife authorities filed cases against the other 18 suspects in the remaining eight cases.

The process of repatriation, rehabilitation, and release of confiscated animals was successful in three cases. Through the efforts of DENR-BMB, the Hong Kong wildlife authority repatriated 57 out of 63 surviving Philippine Forest Turtles in two smuggling incidents to the Philippines in 2012 (Schoppe et al., 2013, Schoppe \& Shepherd, 2013). In another case involving the record-breaking seizure of almost 4,000 Philippine Forest Turtles, $89 \%$ were successfully released back to the wild (Devanadera et al., 2015; Schoppe et al., 2016).

\section{Domestic trade}

Online surveys from January 2017 and December 2018 documented the trade of Philippine Forest Turtles. Between December 2017 and April 2018, three known wildlife traffickers in the Philippines, two of whom were convicted in courts (TRAFFIC, unpubl. data), offered a minimum of 22 Philippine Forest Turtles on Facebook for up to PHP15,500 (ca. USD 300) each (Figs. 5a-b). Physical market surveys conducted by one of us (EYS) did not observe the species although one of the online traders had a physical shop in Cartimar Pet Center.

\section{International online trade}

Large quantities of smuggled Philippine Forest Turtles were offered for sale online in China in 2015 (Sy, unpubl. data). Eighteen unique advertisements offering the species were documented on a Chinese turtle trading website between February 2015 and September 2015 (Fig. 6). Eleven advertisements indicated exact or minimum quantity, while seven advertisements indicated the total weight only $(1,125 \mathrm{~kg})$. The weight of advertised turtles ranged from $250-2,000 \mathrm{~g} /$ individual. Estimating an average size of $20 \mathrm{~cm}$ straight carapace length (SCL) and a weight of $1 \mathrm{~kg}$ /individual turtle, the 


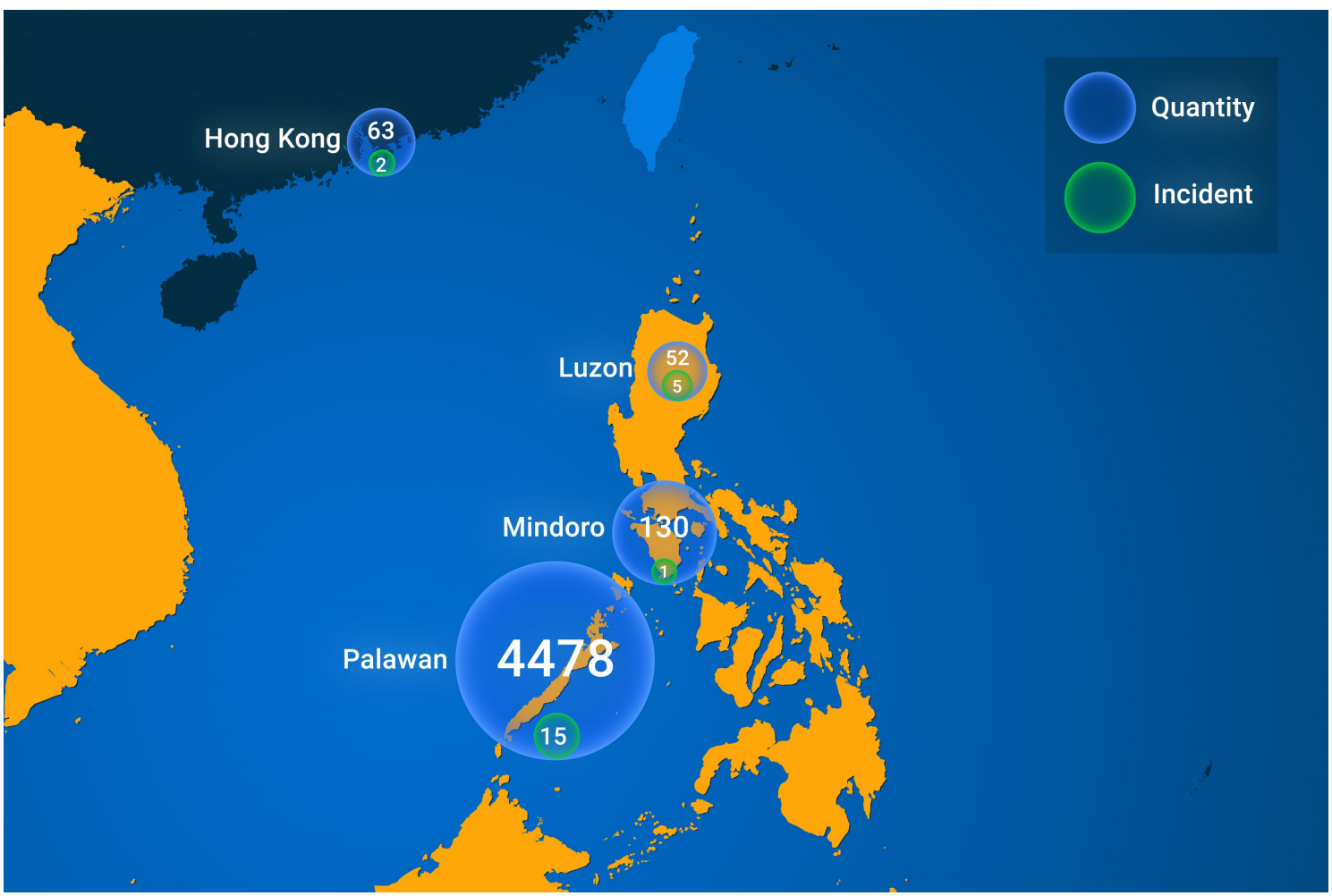

Figure 3. Number of seizure incidents and seized quantity by location.

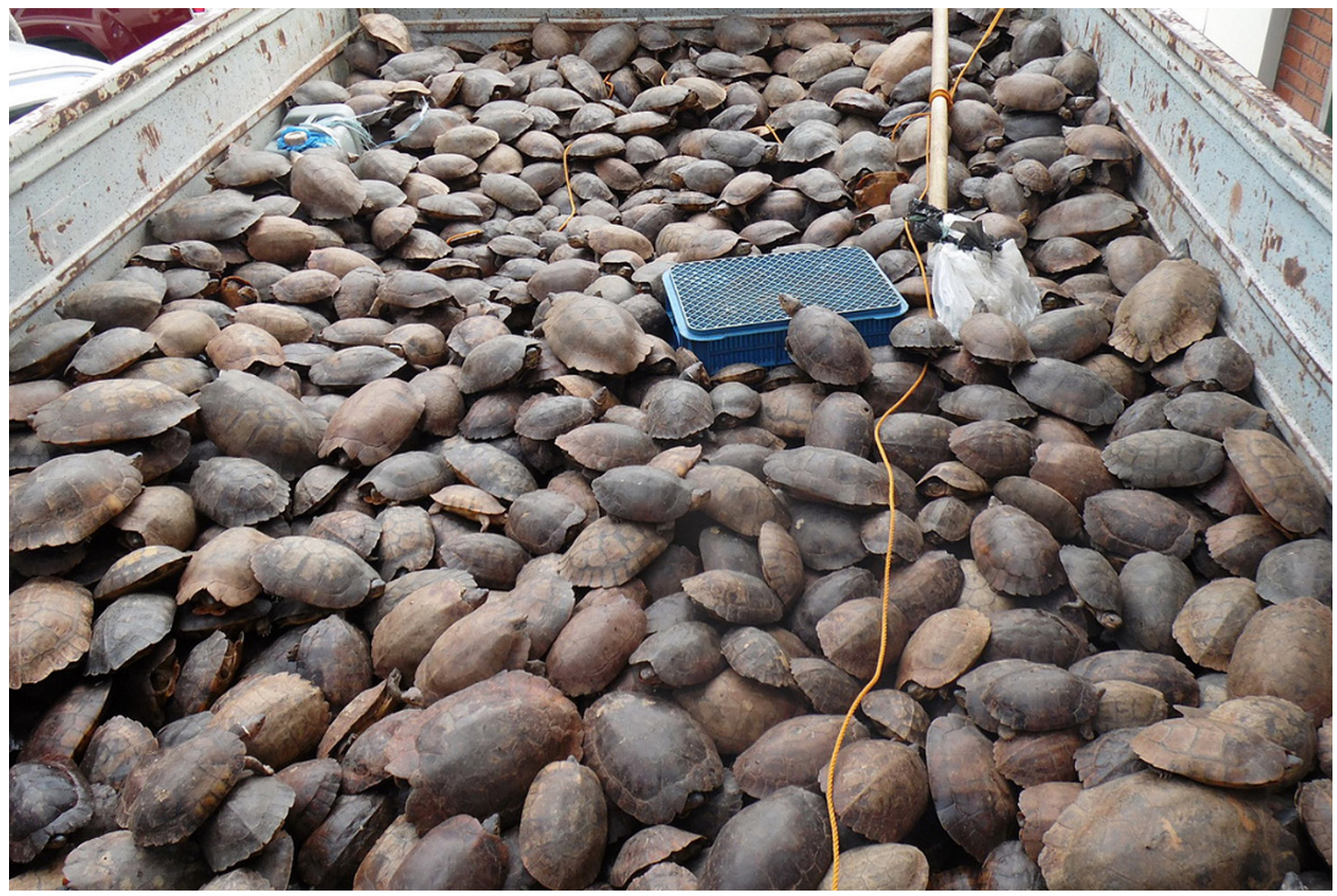

Figure 4. The biggest seizure of illegally caught turtles for trade involving 4,402 turtles occurred in Palawan Province in 2015. C Katala Foundation 


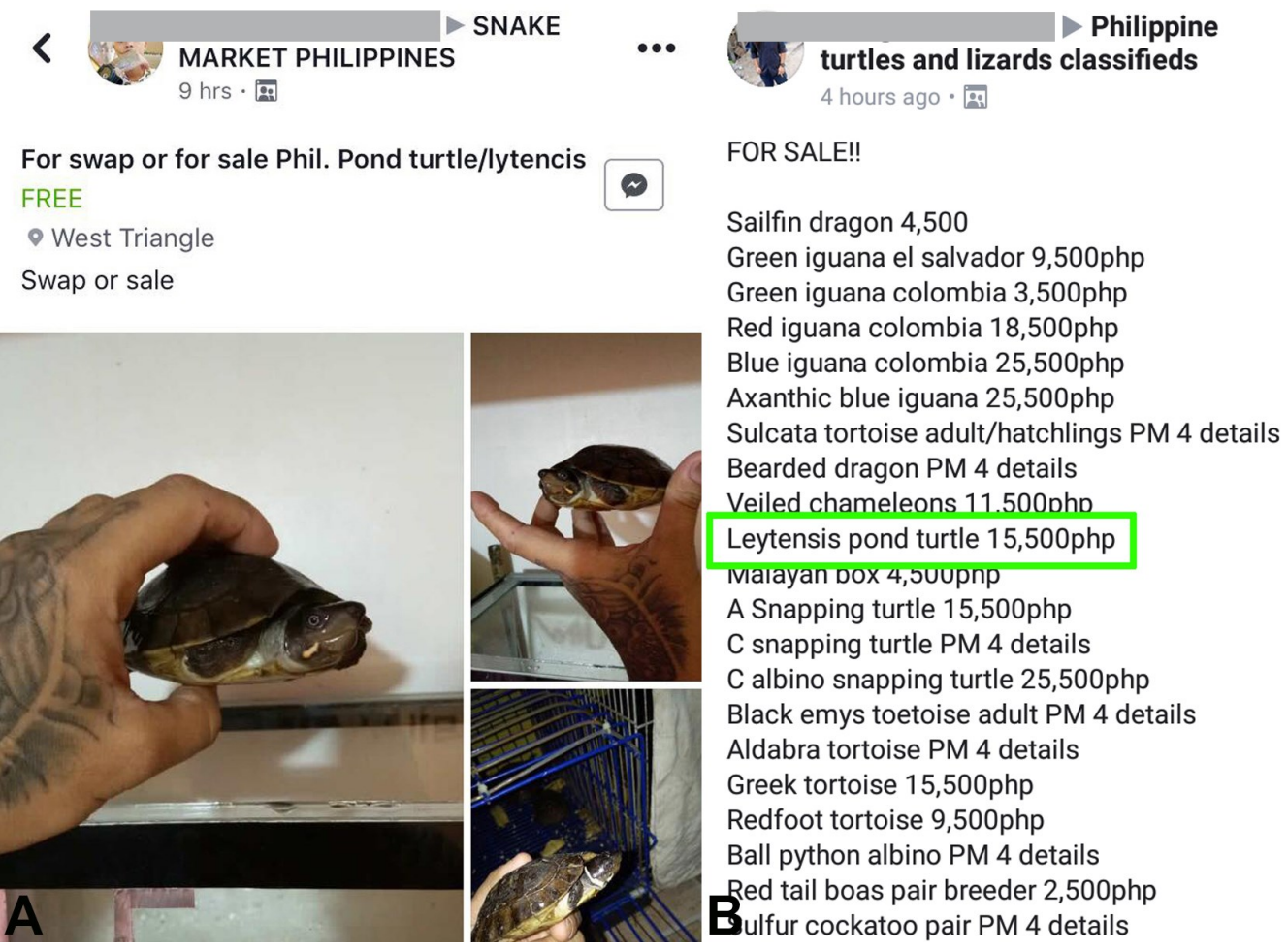

Figure 5a-b. Philippine Forest Turtles offered for sale in Facebook groups.

total quantity offered for sale during the period may have reached up to 1,200 individuals.

\section{Discussion}

Seizures reflect trafficking levels and enforcement efforts. However, the dataset included in this analysis is not an actual representative of the complete seizure incidents involving the species outside of the Philippines, excluding the two Hong Kong cases. Seizure incidents of the Philippine Forest Turtle in the last three years have declined; however, poaching and illegal trade continue as exemplified by the presence of the species in both domestic and international online pet markets (Jansen \& Sy, in press).

Wildlife traffickers in Palawan Province utilize both commercial sea vessels and smaller private boats to transport illegal wildlife to nearby major islands (e.g. Luzon, Mindoro, Negros). This transport method is also used to transport the Philippine Forest Turtle (Fig. 7). Live Philippine Forest Turtles are usually placed in polypropylene sacks or cardboard boxes and purposely misdeclared as agricultural products when being transported in commercial sea vessels. A $57 \mathrm{~cm} \times 100 \mathrm{~cm}$ polypropylene sack can fit 25 to 30 Philippine Forest Turtles with $15-20 \mathrm{~cm}$ SCL. Concealing wildlife in check-in luggage when travelling through airports is another method employed by smugglers. While there has been no reported cases of outbound turtle smuggling by air from the Philippines, the case of a smuggler caught twice at Hong Kong International Airport in 2012 after leaving the Philippines with smuggled wildlife illustrates the challenges to detect trafficking at the Ninoy Aquino International Airport in Manila and other Philippine airports.

Eight out of 15 seizure cases in Palawan Province occurred in the Municipality of Taytay, which suggests its important role as an exit point of the Philippine Forest Turtle. No suspects were arrested in the two cases at the Port of Liminangcong and one case at the Port of El Nido since traffickers abandoned or disowned the illegal wildlife when detected by authorities. The destination of Philippine Forest turtles seized in northern Palawan was likely Metro Manila while individuals seized in southern Palawan were to be smuggled to China.

The presence of illegally collected Philippine Forest Turtles in domestic physical markets, particularly in Metro Manila, has been documented consistently since 2004 (Diesmos et al., 2012; Sy, 2015; Sy, 2018). This is a strong indication that the species is continuously being smuggled out of Palawan and may have been brought about by the lenient security practices by port personnel and authorities.

Large individuals (> $25 \mathrm{~cm} \mathrm{SCL}$ ) were common in Manila markets from 2004-2009, but mainly smaller individuals (8-15 
$\mathrm{cm}$

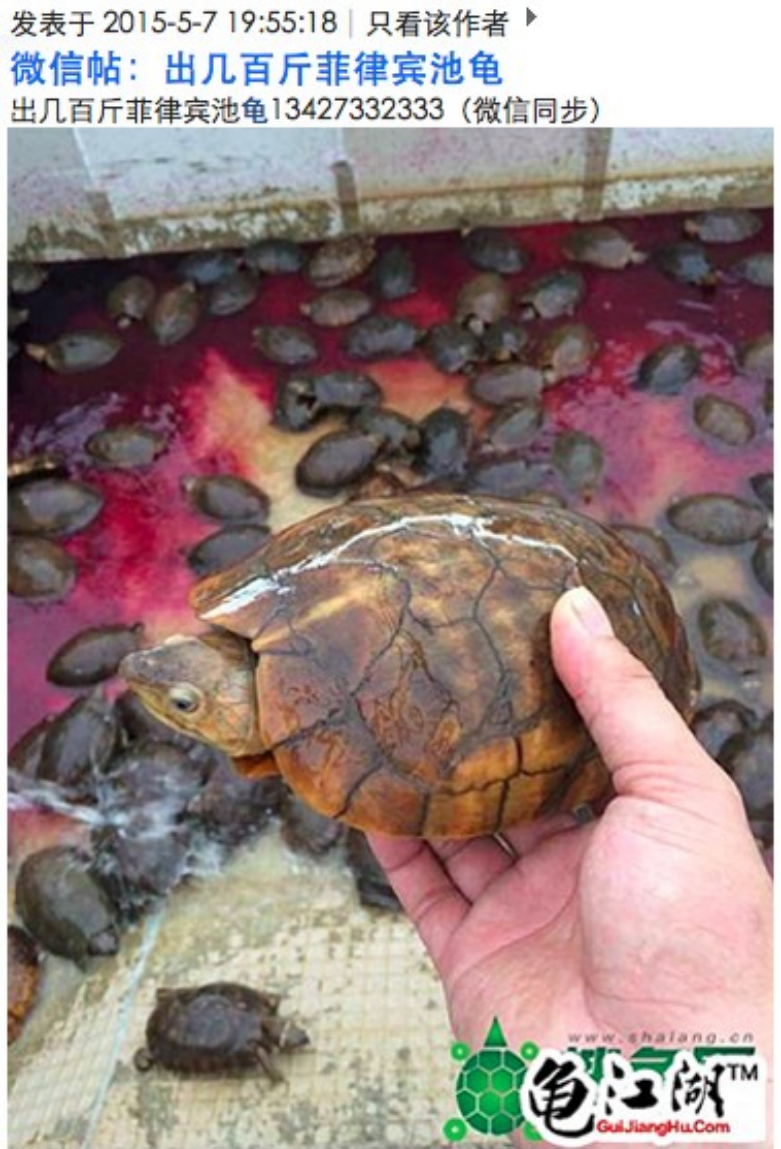

Figure 6. Smuggled Philippine Forest Turtles being offered for sale online in China in 2015. Screen captured by Emerson Y. Sy/TRAFFIC

SCL) were observed for sale in domestic and online markets in the last 10 years (Sy, unpubl. data). The change in size availability in the black market may indicate that larger individuals are less frequently encountered in the wild by poachers or buyers are requesting smaller individuals due to the ease of smuggling them outside the country for wildlife laundering purposes. In contrast, measured seized individuals $(\mathrm{n}=154)$ in Bataraza in 2015 had mean median carapace length of $18.35(+/-2.65) \mathrm{cm}$ and mean body weight of $874.3(+/-$ 465.1) grams (Schoppe, unpubl. data). Traffickers in China may prefer adult individuals for captive breeding purposes.

Wildlife traffickers have also been utilizing online platforms (e.g. Facebook) more often in the last 20 years to engage in domestic and international illegal wildlife trade (Sy, 2018). Given that no facilities are involved in the captive commercial breeding for the species in the Philippines, the Philippine Forest Turtles observed for sale in Facebook were wild caught and then successfully smuggled from Palawan to Metro Manila. These turtles are also being sold internationally, such as in China, Hong Kong, Japan, Malaysia, Taiwan, Thailand, United States, Belgium, Czech Republic, Germany, and United Kingdom (Sy, 2018; Janssen \& Sy, in press; Sy, unpubl. data). The international price for a juvenile specimen varied greatly between USD223 in Hong Kong and up to USD4,500 in the United States (Sy, 2014; Sy, unpubl. data).

The estimated 1,200 Philippine Forest Turtles offered for sale in a Chinese turtle trading website illustrate the ability of smugglers to move large quantities of wildlife internationally from Palawan. We estimated that more than 2,500 Philippine Forest Turtles were illegally traded domestically and internationally in the last 15 years based on a previous estimate of >1,000 individuals from 2004-2014 (Diesmos et al., 2012), 1,200 individuals smuggled to China in 2015, and $>300$ individuals observed in physical and online market surveys between 2013 and 2018 (Sy, 2018; Sy \& Lorenzo, unpubl. data).

\section{Wildlife Laundering}

The Philippine Forest Turtle is widely recognized as being notoriously hard to breed in captivity. Based on information in the CITES Trade database, the Philippines exported 74 apparently captive bred individuals to the United States, Czech Republic, and United Kingdom between 2011 and 2018. However, there is high probability that such individuals were in fact sourced illegally from the wild and were fraudulently declared as captive bred by exporters to obtain CITES export permits.

There was no credible evidence to authenticate captive breeding successes in the Philippines or elsewhere prior to 2018 (Schoppe et al., 2013; Sy, 2014, 2018; Schoppe, 2015). It was only on 24 June 2018 that the first documented captive bred Philippine Forest Turtle was reported (Katala Foundation, 2018; Fig. 8). A zoological park in Rizal Province reported captive

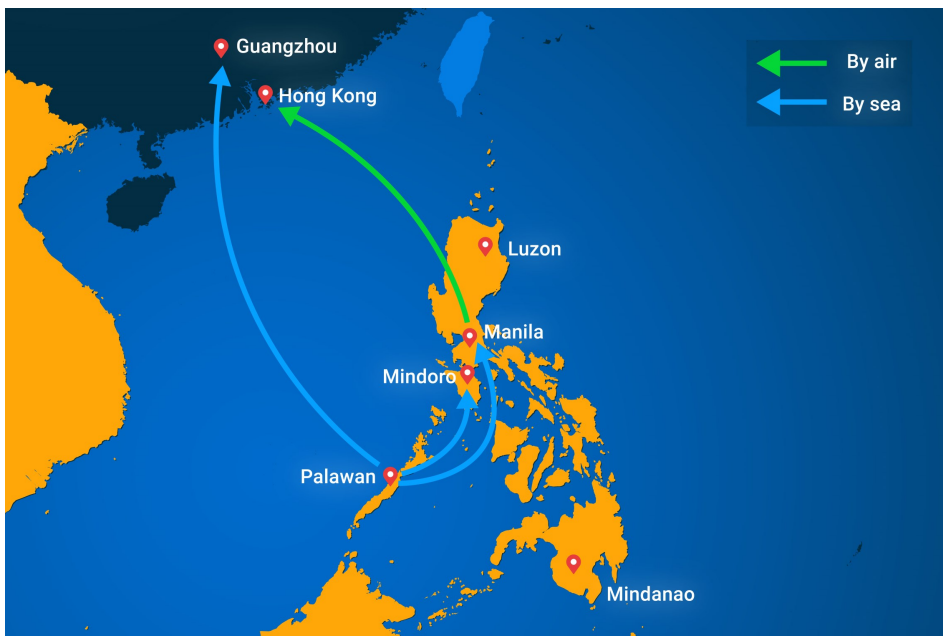

Figure 7. Smuggling routes of the Philippine Forest Turtle based on seizure records between 2004 and 2018. Blue line indicates smuggling by sea; green line indicates smuggling by air. 


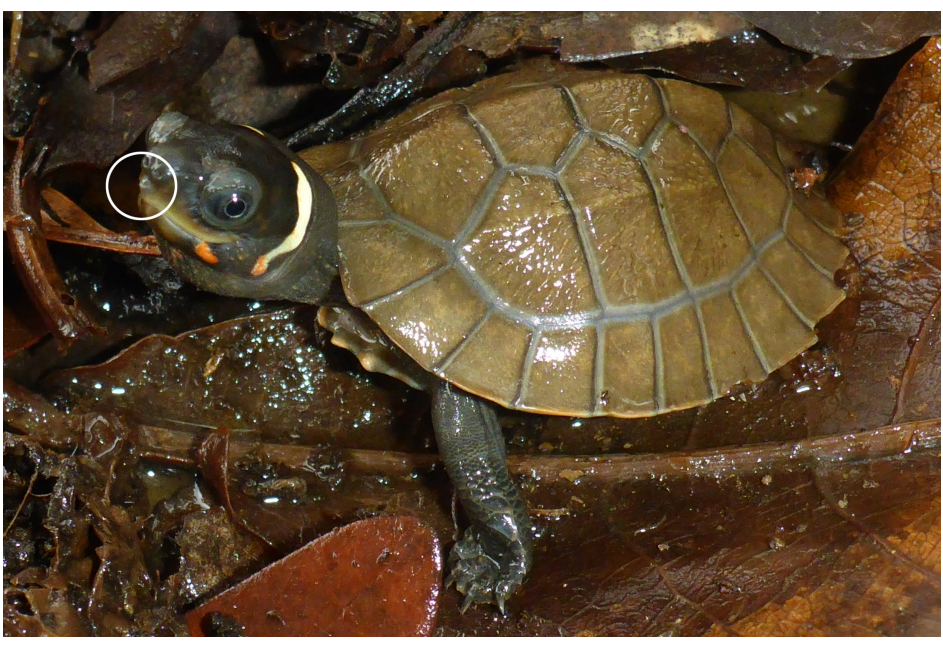

Figure 8. The first documented captive bred Philippine Forest Turtle with the egg tooth (encircled) still intact. (C) Katala Foundation

breeding of 50 second filial generation (F2) Philippine Forest Turtles that apparently all hatched at the same time on 10 July 2016. In April 2017, the zoo attempted to export 30 of the supposedly F2 turtles to the United States, but the Philippine CITES Management Authority did not issue a permit due to the proponent's inability to authenticate its captive breeding claims.

Since the enactment of the Wildlife Conservation and Protection Act of 2001, the Philippine government has not issued permits to collect and/or trade wild caught native reptiles. Only captive bred reptiles from DENR-registered facilities are allowed to be traded for commercial purposes. However, the practice of illegally acquiring wild caught reptiles, then declaring them as captive bred by a few DENRregistered zoological facilities and wildlife breeding farms in the Philippines continues until today. This malpractice receives little scrutiny from wildlife authorities. This has been observed in a number of native Philippine reptiles (e.g. turtles, pit vipers, false geckos, monitor lizards) that are highly sought-after by international private collectors and zoological facilities. For example, a now defunct private wildlife breeding farm in Oriental Mindoro Province was able to legally export 14 purportedly captive bred Varanus olivaceus Hallowell to the United States in 2006 (Bennett, 2014).

\section{Conclusion and Recommendations}

While habitat loss and degradation are a major threat to the survival of the Philippine Forest Turtle, unabated poaching and trafficking for the pet trade remain the biggest threat to the survival of this species in the wild. The ability of traffickers to move large volumes of turtles with impunity across the various Philippine islands and onwards to foreign markets warrants in- depth investigation. More rigid and swift enforcement is strongly urged to enhance protection of the species in situ. Timely enforcement actions against traffickers in Palawan Province, more successful prosecution and conviction with maximum penalties could serve as a strong deterrent to wildlife traffickers. The following are additional recommendations to further strengthen enforcement measures in mitigating the continuous trafficking of the Philippine Forest Turtle:

(1) Immediate declaration of a trade moratorium, and simultaneous conduct of inventory of all previously-registered captive Philippine Forest Turtles in private and public facilities in the country. This will help ascertain whether or not there are parental stocks that are producing progenies that meet the requirements for trading under existing laws, rules, and regulations; (2) Investigate animal exchange or transfer programs for conservation that may be used as fronts for illegal commercial trade, including fraudulent claims of captive breeding, to ensure that no issuance of new permits/licenses will be provided for turtles that may have been acquired illegally. Among the verifiable pieces of evidence that may be used to substantiate breeding success are comprehensive breeding records, egg shells, photo or video documentation, and actual hatchlings with egg tooth and umbilical scar; (3) The participation of national academic and scientific experts on the subject matter must be strengthened to support investigators and enforcers in the validation of evidence; (4) Local communities living near possible Philippine Forest Turtle habitats should be made aware of the importance of the continuous survival of the species and how this will benefit them, so they can actively participate in reporting illegal activities and help protect the habitats of the species; and (5) Conservation groups working on this species should continue to be vigilant in documenting ongoing poaching and illegal trade in order to provide support to the wildlife authorities for enforcement activities and to help educate the public on the plight of this critically endangered turtle.

\section{Acknowledgements}

We thank colleagues from the Biodiversity Management Bureau of the Department of Environment and Natural Resources, CENRO-San Jose, and Palawan Council for Sustainable Development Staff especially Josefina de Leon, Adelina Benavente-Villena, Niño Estoya, and Neil Anthony Del Mundo for providing critical information. EYS thanks Kanitha Krishnasamy and Serene Chng for providing comments on an earlier draft, Or Oi Ching for assisting in translation of Chinese advertisements, Faril Izzadi for working on the maps, and a donor who wishes to remain anonymous for generously funding 
a wildlife trade research program in the Philippines.

We dedicate this study to National Scientist Angel C. Alcala who recently celebrated his $90^{\text {th }}$ birthday on 1 March 2019.

\section{Literature Cited}

Alcala, A.C., 1986. Guide to Philippine Flora and Fauna, Volume X. Amphibians and Reptiles. Natural Resources Management Center, Ministry of Natural Resources, and University of the Philippines. xiv $+195 \mathrm{pp}$.

Bennett, D., 2014. A dubious account of breeding Varanus olivaceus in captivity at the Paradise Reptile Zoo in Mindoro, Philippines. Biawak, 8(1): 12-14.

Cayubit, R.A., 2017. DENR seizes 40 Leyte pond turtles. Manila Bulletin, 8 May 2017. Available at: https:// news.mb.com.ph/2017/05/08/denr-seizes-40-leyte-pondturtles/

Devanadera, N., V. de Guzman \& S. Schoppe., 2015. The Palawan Turtle Rescue. Turtle Survival Alliance: 46-48.

Diesmos, A.C., J.R. Buskirk, S. Schoppe, M.L.L. Diesmos, E.Y. Sy \& R.M. Brown, 2012. Siebenrockiella leytensis (Taylor, 1920) - Palawan Forest Turtle, Philippine Forest Turtle. In: Rhodin, A.G.J. et al., (eds.), Conservation Biology of Freshwater Turtles and Tortoises: A compilation project of the IUCN/SSC Tortoise and Freshwater Turtle Specialist Group. Chelonian Research Monographs, 5: 066.1-066.9.

Diesmos, A.C., G.V.A. Gee, M.L.L. Diesmos, R.M. Brown, P.J. Widmann \& J.C. Dimalibot., 2004. Rediscovery of the Philippine Forest Turtle, Heosemys leytensis (Chelonia; Bataguridae), from Palawan Island, Philippines. Asiatic Herpetological Research, 10: 22-27.

IUCN/SSC Tortoise and Freshwater Turtle Specialist Group and Asian Turtle Trade Working Group. 2000. Recommended changes to 1996 IUCN red list status of Asian turtle species. In: Van Dijk, P.P., B.L. Stuart \& A.G.J. Rhodin (eds.). Asian Turtle Trade: Proceedings of a workshop on conservation and trade of freshwater turtles and tortoises in Asia, Phnom Penh, Cambodia, 1-4 December 1999. Chelonian Research Monographs, 2: 56-164.

Janssen, J. \& E.Y. Sy., In press. Note on the availability of Philippine Forest Turtle Siebenrockiella leytensis in online reptile markets. Palawan Scientist, 12.

Katala Foundation, 2018. First-ever critically endangered Palawan Forest Turtle hatched under human care. Available at: $\quad$ https://www.philippinecockatoo.org/images/ Publications\%20and\%20articles/Press\%20Releases/Press\% 20release $\% 202018 \% 20 \mathrm{CB} \% 20$ of $\% 20$ S. $\% 20$ leytensis $\% 20$ (16\%20July\%202018,\%2011am).pdf
Schoppe, S., 2014. It takes a village. The Tortoise, 46-49.

Schoppe, S. 2015. Die Philippinische Waldschildkröte - 10 Jahre nach ihrer Wiederentdeckung. ZGAP Mitteilungen, 1: 14-17.

Schoppe, S., S. Luz, D. Acosta, R. Mesicampo \& R. Esuma, 2016. Emergency release program for critically endangered Palawan Forest Turtles. Turtle Survival Alliance: 48-50.

Schoppe, S. \& C.R. Shepherd, 2013. The Palawan Forest Turtle: Under threat from international trade. TRAFFIC Bulletin, 25 (1): 9-11.

Schoppe, S., C.S. Shepherd \& C. Beastall. 2013, The Palawan Forest Turtle. The Tortoise, 1(2): 108-117.

Sy, E.Y., 2014. Siebenrockiella leytensis (Philippine Forest Turtle) artificial incubation and hatchling size. Herpetological Review, 45(3): 454-455.

Sy, E.Y., 2015. Turtles and tortoises in the Philippine pet trade. Red Rhino Publishing, Manila. 105 pp.

Sy, E.Y., 2018. Trading faces: Utilisation of Facebook to trade live reptiles in the Philippines. TRAFFIC, Petaling Jaya, Selangor, Malaysia. vii +34 pp.

Timmerman, W.W. \& D.L. Auth., 1988. Geographic distribution: Heosemys leytensis (Leyte Pond Turtle). Herpetological Review, 19(1): 21.

Turtle Conservation Fund, 2003. The world's top 25 most endangered turtles. Available at: https:// turtleconservationfund.org/wp-content/uploads/2008/02/ top25turtlesprofiles.pdf 